\title{
Entomoplasma freundtii sp. nov., a new species from a green tiger beetle (Coleoptera: Cicindelidae)
}

\author{
Joseph G. Tully, ${ }^{1}$ Robert F. Whitcomb, ${ }^{2}$ Kevin J. Hackett, ${ }^{3}$ David L. \\ Williamson, ${ }^{4}$ Frederic Laigret, ${ }^{5}$ Patricia Carle, ${ }^{5}$ Joseph M. Bové, ${ }^{5}$ \\ Roberta B. Henegar, ${ }^{2}$ Nicole M. Ellis, ${ }^{6}$ Deborah E. Dodge ${ }^{6}$ \\ and Jean Adams ${ }^{3}$
}

\footnotetext{
1 Mycoplasma Section, Laboratory of Molecular Microbiology, National Institute of Allergy \& Infectious Diseases, Bldg 550, Frederick Cancer Research Facility, Frederick, MD 217021201, USA

2,3 Vegetable Laboratory ${ }^{2}$ and Insect Biocontrol Laboratory ${ }^{3}$, US Department of Agriculture, Beltsville, MD 20705, USA

${ }^{4}$ Department of Anatomical Sciences, State University of New York, Stony Brook, NY 11794, USA

${ }^{5}$ Laboratoire de Biologie Cellulaire et Moléculaire, Institut National de la Recherche Agronomique and Université de Bordeaux II, 33833 Villenave d'Ornon, France

${ }^{6}$ Perkin-Elmer Applied Biosystems, Foster City, CA 94404, USA
}

\author{
Author for correspondence: Joseph G. Tully. Tel: +1 301846 1192. Fax: + 13018465165 \\ e-mail: jvt $(a$ cu.nih.gov
}

\begin{abstract}
A mollicute (strain BARC $318^{\top}$ ) isolated from gut tissue of a green tiger beetle (Coleoptera: Cicindelidae) was found by dark-field microscopy to consist of non-helical, non-motile, pleomorphic coccoid forms of various sizes. In ultrastructural studies, individual cells varied in diameter from 300 to $1200 \mathrm{~nm}$, were surrounded by a cytoplasmic membrane and showed no evidence of cell wall. The organisms were readily filterable through membrane filters with mean pore diameters of 450 and $300 \mathrm{~nm}$, with unusually large numbers of organisms filterable through $200 \mathrm{~nm}$ pore membrane filters. Growth occurred over a temperature range of $15-32{ }^{\circ} \mathrm{C}$ with optimum growth at $30{ }^{\circ} \mathrm{C}$. The organism fermented glucose and hydrolysed arginine but did not hydrolyse urea. Strain BARC $318^{\top}$ was insensitive to $500 \mathrm{U}$ penicillin $\mathrm{ml}^{-1}$ and required serum or cholesterol for growth. It was serologically distinct from all currently described sterol-requiring, fermentative Mycoplasma species and from 12 nonsterol-requiring Mesoplasma species, 13 non-sterol-requiring Acholeplasma species and 5 previously described sterol-requiring Entomoplasma species. Strain BARC $318^{\top}$ was shown to have a G+C content of $34 \mathrm{~mol} \%$ and a genome size of $870 \mathrm{kbp}$. The 165 rDNA sequence of strain BARC $318^{\top}$ was compared to 165 rDNA sequences of several other Entomoplasma species and to other representative species of the genera Spiroplasma and Mycoplasma, and to other members of the class Mollicutes. These comparisons indicated that strain BARC $318^{\top}$ had close phylogenetic relationships to other Entomoplasma species. On the basis of these findings and other similarities in morphology, growth and temperature requirements and genomic features, the organism was assigned to the genus Entomoplasma. Strain BARC $318^{\top}$ (ATCC 51999') is designated the type strain of Entomoplasma freundtii sp. nov.
\end{abstract}

Keywords: Entomoplasma freundtii sp. nov., mollicute, green tiger beetle

\section{INTRODUCTION}

The reported occurrence of a variety of wall-less prokaryotes (class Mollicutes) in numerous insect and plant hosts has posed a number of taxonomic problems (27). In earlier studies on mollicutes in such habitats, helical organisms were assigned to the genus Spiroplasma $(36,46)$, while non-helical, wall-less organisms

The GenBank accession number for the sequence reported in this paper is AF036954. were assigned to Mycoplasma or Acholeplasma (18, $33-35,39,45)$, depending upon their sterol growth requirement. However, phylogenetic analysis of mollicutes from a variety of habitats (41) and additional genetic and physiological information (genome size, codon usage, glucose transport enzymes) $(5,6,19,20)$ from some non-helical mollicutes from insect/plant habitats clearly define many of these organisms as distinct from classic Acholeplasma or Mycoplasma species. Although a few of the organisms have proved to be true acholeplasmas (38), most of them belong to 
a distinct lineage that has arisen from the spiroplasmas (41). These findings resulted in a proposed revision of the taxonomy of the class Mollicutes (31) in which insect- and plant-derived mollicutes were combined in a new order Entomoplasmatales, with helical mollicutes (family Spiroplasmataceae, genus Spiroplasma) and non-helical mollicutes (Entomoplasmataceae) being accorded separate status.

All members of the Entomoplasmataceae of insect or plant origin have been found to have an optimum growth temperature of $30^{\circ} \mathrm{C}$ and a genome size between 790 and $1140 \mathrm{kbp}$. Organisms with a clear growth requirement for cholesterol were assigned to the genus Entomoplasma, which now contains five recognized species $(31,32)$. Non-helical mollicutes without a cholesterol requirement but with a requirement for small fatty acid supplements were placed in the genus Mesoplasma $(31,37)$. Thirteen species in this genus are presently recognized (32).

A filterable, non-helical and non-motile mollicute, designated strain BARC $318^{\mathrm{T}}$, was isolated in June 1987 from the gut contents of a green tiger beetle (Coleoptera: Cicindelidae). The insect was collected in an upland deciduous woodland area with sandy soil at the Beltsville Agricultural Research Center, MD, USA. The non-helical morphology and non-motile activity of the organism excluded assignment of the organism to the genus Spiroplasma, so further efforts were made to determine whether the organism might belong to other genera within the class Mollicutes (Acholeplasma, Mesoplasma or Entomoplasma). These comparative studies eventually established that the organism was similar in a number of critical biological properties to non-helical mollicutes assigned to the genus Entomoplasma, although it was serologically distinct from the five Entomoplasma species previously described. In this report we provide the specific characteristics of strain BARC $318^{\mathrm{T}}$ in fulfilment of the minimum standards for new species descriptions within the class Mollicutes (14) and propose the name Entomoplasma freundtii sp. nov.

\section{METHODS}

Organisms. Gut contents from a green tiger beetle (Cicindelidae) were transferred to M1D medium (42) containing $500 \mathrm{U}$ penicillin $\mathrm{ml}^{-1}$ and the suspension was passed through a sterile $450 \mathrm{~nm}$ membrane filter. The filtrate was incubated at $30^{\circ} \mathrm{C}$ and after $7 \mathrm{~d}$ the broth culture displayed an acidic shift in $\mathrm{pH}$. Dark-field examination of the culture revealed numerous non-helical, non-motile organisms. Strain BARC $318^{\mathrm{T}}$ was then purified by conventional filtration cloning techniques (28). Type strains of five previously recognized species of the genus Entomoplasma (32) were also employed in comparative studies with strain BARC $318^{\mathrm{T}}$ (Table 1).

Culture medium and cultivation techniques. SP-4 (42) or M1D culture media were used for most characterization work. In biochemical and sterol test procedures, strain BARC $318^{\mathrm{T}}$ was adapted to grow in a reduced serum medium containing $1 \%$ bovine serum fraction (42). Agar formulations of SP-4 medium were prepared by adding Noble agar (Difco) to a final concentration of $0.8 \%$. Temperature requirements for growth, including optimum temperature and temperature range, were assessed as previously described (16). Following the results of these tests, most characterization studies were performed at $30^{\circ} \mathrm{C}$ with agar cultures incubated anaerobically in the Gaspak system (BBL Microbiology Systems).

Morphological studies. Cells of strain BARC $318^{\mathrm{T}}$ in exponential phase were examined by dark-field microscopy at a magnification of $\times 1250$. The ultrastructure of this strain, as determined by electron microscopic examination of sectioned cells, was determined as previously reported (44).

Sterol requirement. Sterol requirement for growth of strain BARC $318^{\mathrm{T}}$ was assayed in a test measuring the ability of the organism to sustain growth in a serum-free medium, in serum-free medium with a fatty acid supplement $(0.04 \%$ polyoxyethylene sorbitan) or in a medium containing $15 \%$ foetal bovine serum $(23,30)$.

Tests for biological and biochemical properties. Procedures for assessing glucose fermentation and hydrolysis of arginine or urea have been described (1). Filtration characteristics of the organism following passage of SP-4 broth cultures through membrane filters of various porosities $(450,300$ and $200 \mathrm{~nm}$ ) were measured by techniques reported previously (28).

Serological tests. Antiserum to strain BARC $318^{\mathrm{T}}$ was produced in rabbits as previously described $(25,29)$. The agar plate growth inhibition test (9) and a metabolism inhibition test in broth (26) were used to compare the response of strain $\mathrm{BARC} 318^{\mathrm{T}}$ to hyperimmune antisera to various Entomoplasma species. In addition, strain BARC $318^{\mathrm{T}}$ was also tested using the growth inhibition procedure against 74 antisera to type strains of all currently established fermentative or non-arginine-hydrolysing Mycoplasma species, to 13 antisera to current Acholeplasma species and to 12

Table 1. Reciprocal metabolism inhibition tests with BARC 318 and established Entomoplasma species

\begin{tabular}{|c|c|c|c|c|c|c|}
\hline \multirow[t]{2}{*}{ Antigen } & \multicolumn{6}{|c|}{ Reciprocal metabolism inhibition titre of hyperimmune sera against strain: } \\
\hline & ELCN-1 ${ }^{\mathrm{T}}$ & PIPN-2 ${ }^{\mathrm{T}}$ & PIMN-1 $^{T}$ & $\mathbf{M 1}^{\mathrm{T}}$ & PYAN-1 ${ }^{\mathrm{T}}$ & BARC 318 \\
\hline Entomoplasma ellychniae ELCN-1 $1^{\mathrm{T}}$ & $>20000$ & 64 & $<16$ & $<16$ & $<16$ & $<16$ \\
\hline Entomoplasma lucivorax PIPN-2 ${ }^{\mathrm{T}}$ & $<16$ & $>20000$ & $<16$ & $<16$ & $<16$ & $<16$ \\
\hline Entomoplasma luminosum PIMN-1 ${ }^{\mathrm{T}}$ & $<16$ & $<16$ & 1280 & $<16$ & $<16$ & $<16$ \\
\hline Entomoplasma melaleucae $\mathrm{M}^{\mathrm{T}}$ & $<16$ & 512 & 64 & $>20000$ & $<16$ & $<16$ \\
\hline Entomoplasma somnilux PYAN-1 ${ }^{\mathrm{T}}$ & $<16$ & $<16$ & $<16$ & $<16$ & $>20000$ & $<16$ \\
\hline Strain BARC $318^{\mathrm{T}}$ & $<16$ & $<16$ & $<16$ & $<16$ & $<16$ & $>20000$ \\
\hline
\end{tabular}


Table 2. Mollicutes and other bacterial species used in this study

\begin{tabular}{|c|c|c|c|}
\hline Species & Strain & $\begin{array}{c}\text { Nucleotide } \\
\text { sequence } \\
\text { accession } \\
\text { no. }\end{array}$ & Reference \\
\hline Acholeplasma laidlawii & PG $8^{\mathrm{T}}$ & U14905 & 2 \\
\hline Anaeroplasma abactoclasticum & $6-1^{\mathrm{T}}$ & M25050 & 41 \\
\hline Asteroleplasma anaerobium & $161^{\mathrm{T}}$ & M22351 & 41 \\
\hline Bacillus subtilis & 168 & M10606 & 13 \\
\hline Clostridium innocuum & $\mathrm{B}-3^{\mathrm{T}}$ & M23732 & 41 \\
\hline Clostridium ramosum & $113-\mathrm{I}^{\mathrm{T}}$ & M23731 & 41 \\
\hline Entomoplasma ellychniae & ELCN-1 ${ }^{\mathrm{T}}$ & M24292 & 41 \\
\hline Entomoplasma freundtii & BARC $318^{\mathrm{T}}$ & AF036954 & This study \\
\hline Entomoplasma melaleucae & $\mathrm{M}^{\mathrm{T}}$ & M24478 & 41 \\
\hline Escherichia coli & $\mathrm{K}-12$ & J01695 & 4 \\
\hline Mesoplasma entomophilum & $\mathrm{TAC}^{\mathrm{T}}$ & M23931 & 41 \\
\hline Mesoplusma lactucae & $831-\mathrm{C} 4^{\mathrm{T}}$ & M24479 & 41 \\
\hline $\begin{array}{l}\text { Mycoplasma capricolum subsp. } \\
\text { capricolum }\end{array}$ & California $\mathrm{Kid}^{\mathrm{T}}$ & X00921 & 15 \\
\hline Mycoplasma hominis & $\mathrm{PG} 21^{\mathrm{T}}$ & M24473 & 41 \\
\hline $\begin{array}{l}\text { Mycoplasma mycoides subsp. } \\
\text { mycoides }\end{array}$ & $P G 1^{T}$ & M23943 & 41 \\
\hline Mycoplasma pneumoniae & $\mathrm{FH}^{\mathrm{T}}$ & M29061 & 41 \\
\hline Mycoplasma putrefaciens & $\mathrm{KS}-1^{\mathrm{T}}$ & M23938 & 41 \\
\hline Phytoplasma apple proliferation & AT & X68375 & 24 \\
\hline Phytoplasma stolbur & STOL & $X 76427$ & 24 \\
\hline Spiroplasma apis & $\mathrm{B}-31^{\mathrm{T}}$ & M23937 & 41 \\
\hline Spiroplusma citri & Maroc/R8A2 $2^{\mathrm{T}}$ & M23942 & 41 \\
\hline Spiroplasma clarkii & $\mathrm{CN}-5^{\mathrm{T}}$ & M24474 & 41 \\
\hline Spiroplasma diabroticae & $\mathrm{DU}-1^{\mathrm{T}}$ & M24482 & 41 \\
\hline Spiroplasma gladiatoris & $\mathrm{TG}-1^{\mathrm{T}}$ & M24475 & 41 \\
\hline Spiroplasma ixodetis & $\mathrm{Y} 32^{\mathrm{T}}$ & M24477 & 41 \\
\hline Spiroplasma mirum & $\mathrm{SMCA}^{\mathrm{T}}$ & M24662 & 41 \\
\hline Spiroplasma monobiae & MQ-1 ${ }^{\mathrm{T}}$ & M24481 & 41 \\
\hline Spiroplasma taiwanense & $\mathrm{CT}-1^{\mathrm{T}}$ & M24476 & 41 \\
\hline Spiroplasma sp. (Drosophila) & DW-1 & M24483 & 41 \\
\hline Streptococcus pneumoniae & NCTC $7465^{\mathrm{T}}$ & X58312 & 3 \\
\hline
\end{tabular}

antisera to established Mesoplasma species (32). These sera originated from a reference collection at the National Institute of Allergy and Infectious Diseases Laboratory, Frederick. MD, USA.

Genomic analysis. The DNA base composition $(\mathrm{G}+\mathrm{C}$ content) of strain BARC $318^{\mathrm{T}}$ was determined by buoyant density and melting temperature using procedures described previously $(7,8)$. Spiroplasma citri DNA $(\mathrm{G}+\mathrm{C}=$ $26 \mathrm{~mol} \%$ ) was used as the control for this procedure. The genome size of strain BARC $318^{\mathrm{T}}$ was determined by PFGE, using techniques outlined previously $(5,6)$.

Sequence determination and phylogenetic analysis. Nucleic acid was extracted from a BARC $318^{\mathrm{T}}$ cell pellet using a Chelex resin/boil protocol (40). Two microlitres of a tenfold dilution of the Chelex extraction was added to a $100 \mu \mathrm{l} \mathrm{PCR}$ reaction containing $50 \mu \mathrm{l}$ Microseq $16 \mathrm{~S}$ rRNA Gene Kit PCR Master Mix (Applied Biosystems) and $48 \mu$ water. The PCR product generated was 1540 bp in length. Prior to cycle sequencing, the PCR products were purified using a Microcon 100 column (Amicon). The product $(100 \mu \mathrm{l})$ was added to the top of the column with $400 \mu 10 \mathrm{mM}$ Tris/ $\mathrm{HCl}$ and
$0 \cdot 1 \mathrm{mM}$ EDTA, pH 8.0. The column was spun at 3000 r.p.m. in an Eppendorf $5415 \mathrm{C}$ benchtop centrifuge for $15 \mathrm{~min}$. The column was then inverted and spun in the centrifuge again at 3000 r.p.m. for $2 \mathrm{~min}$. The purified product was then brought up to a volume of $50 \mu \mathrm{l}$ with $10 \mathrm{mM}$ Tris $/ \mathrm{HCl}$ and $0 \cdot 1 \mathrm{mM}$ EDTA, pH 8.0.

For cycle sequencing, the Microseq 16S rRNA Gene Kit Sequencing Module (Applied Biosystems) was used according to the manufacturer's instructions. The reactions were cycled using a Gene Amp 9600 Thermal Cycler (PerkinElmer). The cycling profile consisted of a $96{ }^{\circ} \mathrm{C} / 10 \mathrm{~s}$ denaturation step, followed by a $58^{\circ} \mathrm{C} / 1 \mathrm{~min}$ annealing/ extension step for a total of 30 cycles. After cycle sequencing, excess dye terminators were removed using Centri-Sept Spin Columns (Princeton Separations) according to the manufacturer's instructions. The reactions were then dried down in a Speed Vac (Savant Instruments) and resuspended in $4 \mu \mathrm{l}$ sequencing gel loading buffer, which consisted of Blue Dextran $(50 \mathrm{mM})$, EDTA $\left(50 \mathrm{mg} \mathrm{ml} \mathrm{m}^{-1}\right)$ and deionized formamide $(1: 5, \mathrm{v} / \mathrm{v})$. The reactions were then loaded onto a 377 DNA Sequencer (Applied Biosystems). Two micro- 
litres of the resuspended reaction were loaded into each lane of the 36-lane gel. A $36 \mathrm{~cm}, 5 \%$ Long Ranger polyacrylamide gel (FMC Bioproducts) was used. The samples were electrophoresed at $1650 \mathrm{~V}$ and $52{ }^{\circ} \mathrm{C}$ for $7 \mathrm{~h}$.

The collected sequences were then analysed using the software programs Sequencing Analysis and Factura (Applied Biosystems). The analysed sequences were then assembled and edited using Auto Assembler (Applied Biosystems) and a consensus sequence was generated. Further comparative analysis was performed using fastDNAml (21) and the data and services provided by the Ribosomal Database Project (17). A phylogenetic tree was constructed using TREEVIEW (22). The accession numbers of sequences used in the phylogenetic analysis in this study are listed in Table 2.

\section{RESULTS AND DISCUSSION}

\section{Cultural and morphological properties}

Strain BARC $318^{\mathrm{T}}$ grew well in either SP-4 or M1D medium and on a solid medium prepared from these formulations. The strain also grew in the Edward formulation of conventional mycoplasma medium (42) containing $15-20 \%$ horse serum, or in conventional mycoplasma medium (42) containing $1 \%$ bovine serum fraction. Growth occurred in broth medium containing $500 \mathrm{U}$ penicillin $\mathrm{ml}^{-1}$. The optimum temperature for growth was $30^{\circ} \mathrm{C}$, with growth occurring over a range of $15-32{ }^{\circ} \mathrm{C}$. No growth was recorded during a 3-week period in broth medium incubated at $37^{\circ} \mathrm{C}$. Agar colonies of strain BARC $318^{\mathrm{T}}$ (Fig. 1) exhibited a granular-type growth, frequently with numerous small satellite colonies and without the typical fried-egg morphology observed with many other mollicutes.

Dark-field microscopy of exponential-phase cultures

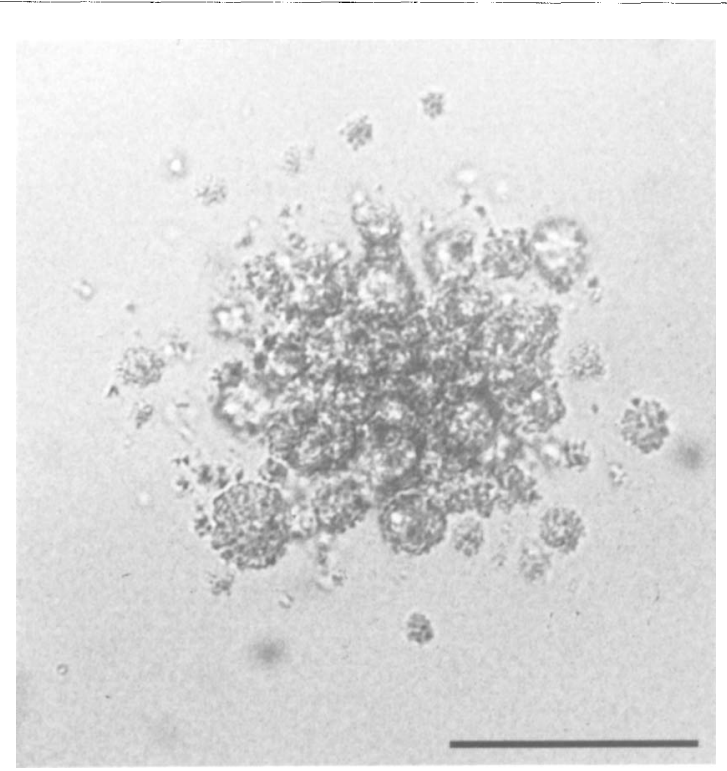

Fig. 1. Colonies of strain BARC $318^{\top}$ on $0.8 \%$ SP-4 agar medium after $9 \mathrm{~d}$ incubation at $30^{\circ} \mathrm{C}$ in an anaerobic environment. Bar, $100 \mu \mathrm{m}$.

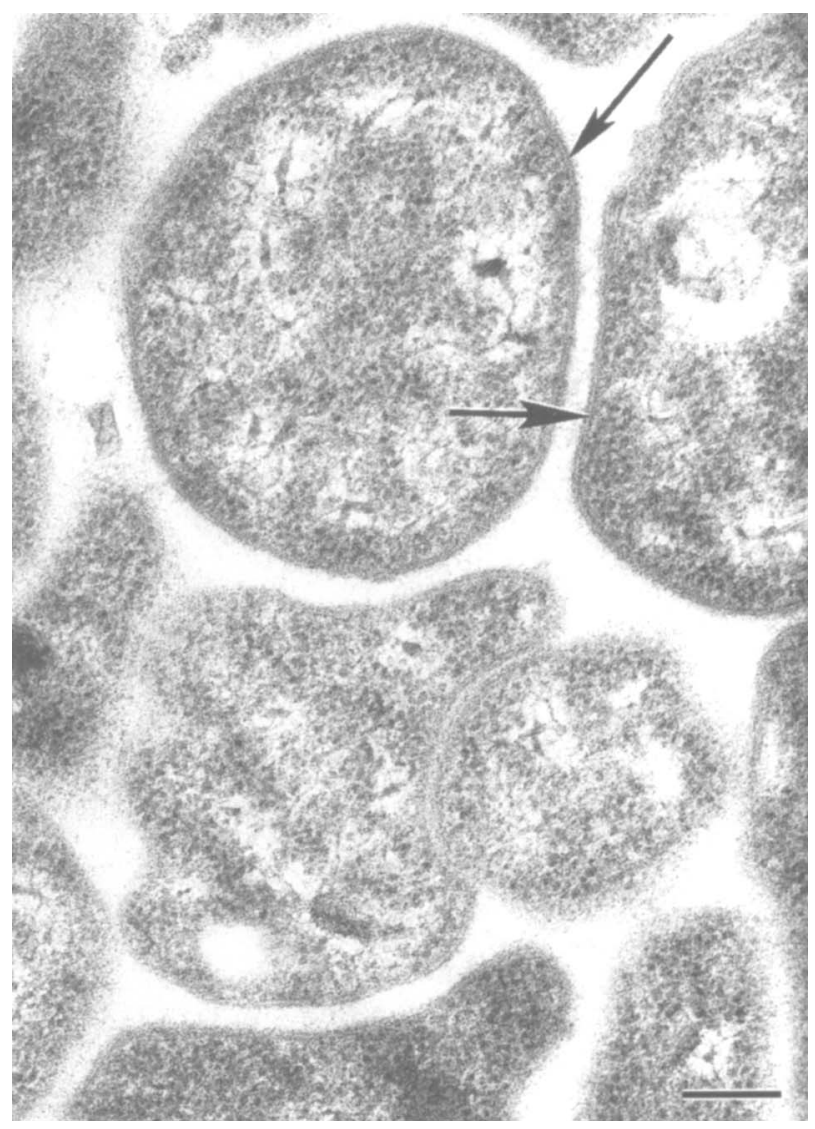

Fig. 2. Electron photomicrograph of a thin section of $B A R C$ $318^{\top}$ cells showing pleomorphic coccoid cells. Arrows indicate single cytoplasmic membrane. Bar, $200 \mathrm{~nm}$.

of strain BARC $318^{\mathrm{T}}$ showed non-helical, non-motile, very pleomorphic forms, mostly coccoid in shape. Sectioned cells observed by electron microscopy also demonstrated a variety of pleomorphic coccoid forms with no evidence of cell wall. Representative cells had a diameter in the range $300-1200 \mathrm{~nm}$ with individual cells surrounded only by a cytoplasmic unit membrane (Fig. 2).

\section{Sterol requirement}

In tests to measure the sustained growth of strain BARC $318^{\text {TT }}$ through 23 serial tenfold passages in three different media, continued growth occurred only in the medium containing $15 \%$ foetal bovine serum. The organism was not able to sustain growth beyond the first tenfold dilution in serum-free medium or in medium containing a $0.04 \%$ polyoxyethylene sorbitan (Tween 80 ) supplement, indicating a growth requirement for cholesterol or serum $(23,30)$.

\section{Biochemical and biological properties}

Strain BARC $318^{\mathrm{T}}$ rapidly fermented glucose with a shift in medium $\mathrm{pH}$ to the acid range within $24 \mathrm{~h}$ at both room temperature and $30^{\circ} \mathrm{C}$. In broth containing 


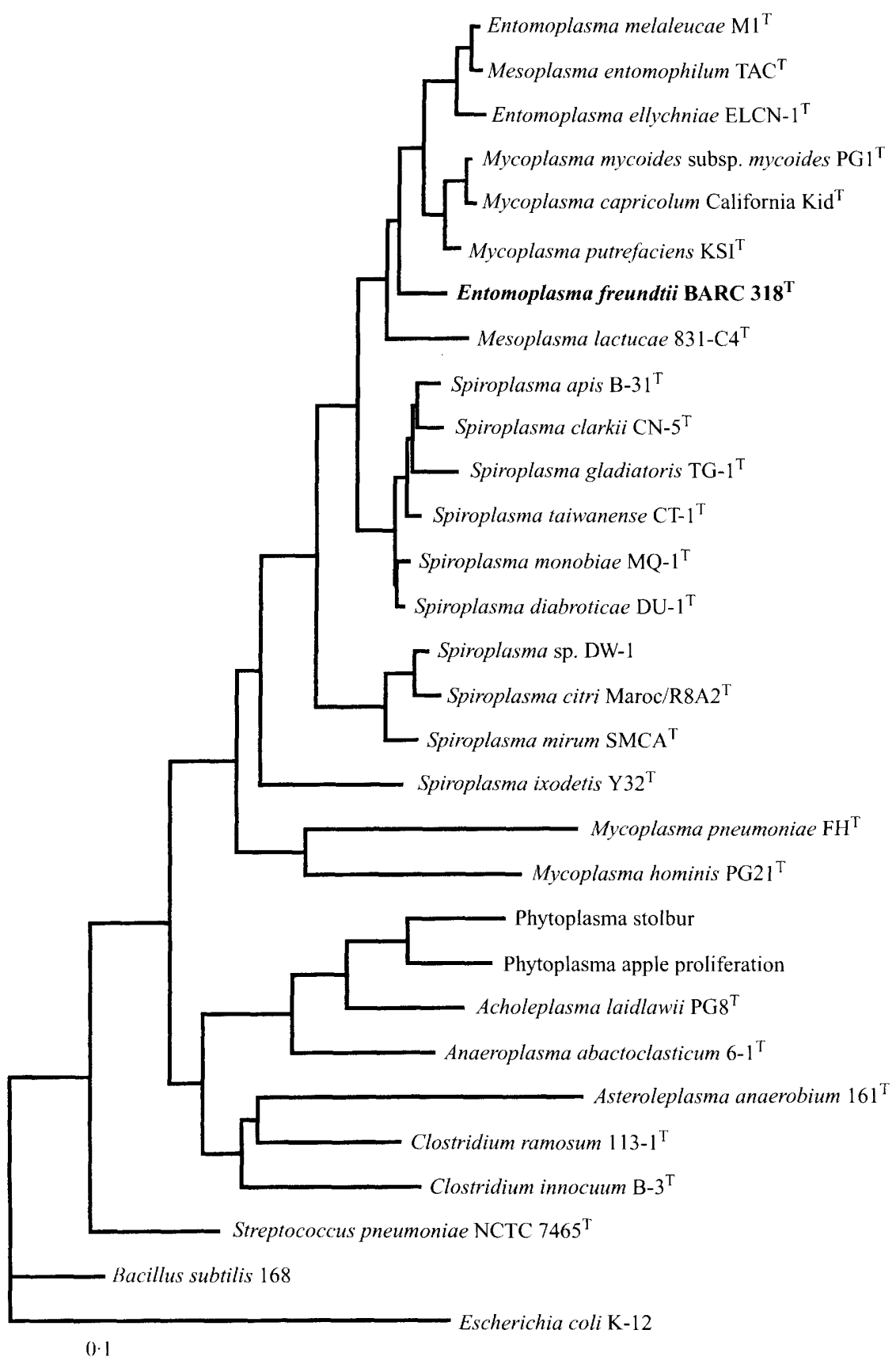

Fig. 3. Dendrogram showing the phylogenetic position of strain BARC $318^{\top}$ in relation to other representatives of the class Mollicutes and to other bacteria, based on $16 S$ rDNA. Scale bar, 10 substitutions per $100 \mathrm{nt}$. arginine but no glucose, the organism induced a slight initial decrease in $\mathrm{pH}$ but later produced a rapid change in medium $\mathrm{pH}$ towards the alkaline range, indicating the hydrolysis of arginine and concomitant production of ammonia. Tests for urea hydrolysis were negative. Passage of broth cultures of strain BARC $318^{\mathrm{T}}$ through 450 or $300 \mathrm{~nm}$ membrane filters did not reduce the viable cell titre $\left[\geqslant 10^{9}\right.$ colourchanging units (c.c.u.) $\mathrm{ml}^{-1}$ ]. The titre of a broth culture filtrate obtained after passage through a membrane with a mean pore diameter of $200 \mathrm{~nm}$ showed a viable cell population reduced by a factor of about $10\left(10^{8}\right.$ c.c.u. $\left.\mathrm{ml}^{-1}\right)$.

\section{Serological tests}

Preliminary growth inhibition tests with strain BARC $318^{\mathrm{T}}$ against 74 antisera to fermentative (or nonarginine-hydrolysing) Mycoplasma species, 13 Acholeplasma species, 12 Mesoplasma species and 5 Entomoplasma species indicated the absence of any serological relationship. Antiserum prepared to strain BARC $318^{\mathrm{T}}$ produced a homologous growth inhibition zone of $5 \mathrm{~mm}$. Since the morphology and growth requirements indicated a closer relationship to Entomoplasma species, more extensive serological testing was carried out with antisera to established species in 
Table 3. Genomic and growth temperature properties of established Entomoplasma species

The optimum growth temperature for all strains was $30^{\circ} \mathrm{C}$. None of the strains grew at $37^{\circ} \mathrm{C}$.

\begin{tabular}{|c|c|c|c|}
\hline Species & $\begin{array}{c}G+C \\
(\mathrm{~mol} \%)\end{array}$ & $\begin{array}{c}\text { Genome } \\
\text { size } \\
(\mathbf{k b p})\end{array}$ & $\begin{array}{c}\text { Growth } \\
\text { temperature } \\
\text { range }\left({ }^{\circ} \mathrm{C}\right)\end{array}$ \\
\hline Entomoplasma ellychniae ELCN-1 ${ }^{\mathrm{T}}$ & $27 \cdot 5$ & 912 & $18-32$ \\
\hline Entomoplasma lucivorax PIPN-2 ${ }^{\mathrm{T}}$ & $27 \cdot 4$ & 1188 & $18-32$ \\
\hline Entomoplasma luminosum PIMN-1 ${ }^{\mathrm{T}}$ & $28 \cdot 8$ & 889 & $10-32$ \\
\hline Entomoplasma melaleucae $\mathrm{M}^{\mathrm{T}}$ & $27 \cdot 0$ & 898 & $10-30$ \\
\hline Entomoplasma somnilux PYAN-1 ${ }^{\mathrm{T}}$ & $27 \cdot 4$ & 822 & $10-32$ \\
\hline BARC $318^{T}$ & $34 \cdot 0$ & 870 & $10-32$ \\
\hline
\end{tabular}

this genus. Reciprocal metabolism inhibition tests were performed with antigens and antisera to five established Entomoplasma species and to strain BARC $318^{\mathrm{T}}$ antigen and its homologous antiserum (Table 1). These additional serological tests again confirmed the lack of any serological relationship between strain BARC $318^{\mathrm{T}}$ and established Entomoplasma species. These findings indicate that antisera to both Mesoplasma and Entomoplasma species should be part of any identification scheme for identifying mollicutes from insect hosts (43).

\section{Genomic characterization}

The $\mathrm{G}+\mathrm{C}$ content of strain BARC $318^{\mathrm{T}}$ was found to be $34 \mathrm{~mol} \%$. The genome size was $870 \mathrm{kbp}$ by PFGE.

\section{Phylogenetic analysis}

The first analysis using the Similarity Rank tool from the Ribosomal Database Project indicated that the BARC $318^{\mathrm{T}} 16 \mathrm{~S}$ rDNA sequence was not identical to any known and deposited sequence. However, it was most closely related to the $16 \mathrm{~S}$ rDNA sequence of organisms considered as the 'Mycoplasma mycoides cluster' (including Mycoplasma capricolum subsp. capricolum and Mycoplasma putrefaciens) within the Spiroplasma group, as defined by Weisburg and colleagues (41). Further phylogenetic analysis was performed using a subset of the database including all the members of the Spiroplasma group sequenced so far, as well as representatives of other phylogenetic groups within the class Mollicutes and their walled relatives. Although unrooted, the tree was constructed using Escherichia coli as an outgroup (Fig. 3). Strain BARC $318^{\mathrm{T}}$ clearly belongs to the Spiroplasma phylogenetic group and more precisely within this group to members of the Mycoplasma mycoides cluster and to organisms assigned to the genera Entomoplasma and Mesoplasma. Indeed, this overall group contains all the non-helical members of the Spiroplasma group sequenced so far. Thus, in the present classification of the class Mollicutes (31), the phylogenetic position of BARC $318^{\mathrm{T}}$ is consistent with its assignment to the genus Entomoplasma.

This reconstruction, and previously constructed trees of the class Mollicutes (41), suggests that phylogenetic distances between some mesoplasmas and some entomoplasmas are very small. Furthermore, Mesoplasma and Entomoplasma may not be monophyletic. At the time that these genera were proposed (31), sterol requirements of mollicutes were considered to be appropriate characteristics for separation of higher mollicute taxa. Since then it has been discovered that members of the genus Spiroplasma defined originally as sterol-requiring, may or may not require sterols (23). Although molecular phylogenetic studies of this genus are incomplete, sterol utilization does not appear to be correlated with phylogeny. It would be useful in future to investigate phylogenetic relationships within the genus Spiroplasma using protein-encoding genes to relate phenotypic characteristics. Very few molecular phylogenetic determinations have been made on Mesoplasma or Entomoplasma species. The confusing profile obtained so far, plus the proximity of the members of the order Entomoplasmatales to the Mycoplasma mycoides cluster, makes further phylogenetic study of the Entomoplasmatales imperative. It is possible that such studies, when completed, could indicate that species within the family Entomoplasmataceae should be classified in a single genus.

\section{Habitat}

The occurrence of strain BARC $318^{\mathrm{T}}$ in the insect gut is consistent with what is presently known of the habitat of other Entomoplasma species. All five currently described Entomoplasma species were isolated from the gut or haemolymph of various firefly beetles (Entomoplasma somnilux, Entomoplasma luminosum, Entomoplasma lucivorax and Entomoplasma ellychniae), or from an anthophorine bee (Entomoplasma melaleucae $)(34,35,45)$. It is also quite likely that BARC $318^{\mathrm{T}}$ and related strains occur on plant surfaces, since some entomoplasmas (e.g. Entomoplasma 
melaleucae) were isolated from flowers of several tropical plants (Melaleuca quinquenervia, Melaleuca decora) and flowers of the silk oak (Grevillea robusta) (35).

The properties of strain BARC $318^{\mathrm{T}}$ described herein fulfill recently revised criteria (14) for new species descriptions in the class Mollicutes. Properties mandating assignment to this class include absence of a cell wall, filterability and penicillin resistance. The nonhelical morphology of strain BARC $318^{\mathrm{T}}$, the optimum growth temperature of $30{ }^{\circ} \mathrm{C}$, the inability to hydrolyse urea and a genome size of $870 \mathrm{kbp}$ place the organism within the order Entomoplasmatales, family Entomoplasmataciae (Table 3) (31). A sterol requirement indicates the organism belongs in the genus Entomoplasma (31). Finally, the lack of a serological relationship of strain BARC $318^{\mathrm{T}}$ to the type strains of previously established Entomoplasma species demonstrates its stature as a distinct species. Accordingly, we propose the name Entomoplasma freundtii sp. nov. for this organism, in consideration of the major contributions and pioneering efforts of Eyvind Freundt in the early characterization and classification of the mollicutes $(10-12)$.

\section{Description of Entomoplasma freundtii sp. nov.}

Entomoplasma freundtii (fr.eun.d'ti.i. M.L. gen. n. freundtii named after Eyvind Freundt, a Danish pioneer in the taxonomy and classification of mollicutes).

Cells predominately coccoid in shape, varying from 300 to $1200 \mathrm{~nm}$ in diameter. Cells devoid of cell wall and surrounded only by cytoplasmic membrane. Nonmotile. Colonies on solid medium with $0.8 \%$ agar are granular and frequently exhibit multiple satellite forms. Chemo-organotroph. Acid produced from glucose. Hydrolyses arginine, but not urea. Serum or sterol required for sustained growth. Growth temperature range, $10-32{ }^{\circ} \mathrm{C}$; optimum growth temperature, $30^{\circ} \mathrm{C}$. Serologically distinct from all other established Entomoplasma species, as well as currently described glucose-fermenting (arginine-non-hydrolysing) Mrcoplasma, Acholeplasma and Mesoplasma species. Isolated from gut contents of a green tiger beetle (Coleoptera: Cicindelidae). Evidence of insect pathogenicity not determined. $\mathrm{G}+\mathrm{C}$ content, $34 \pm 1$ $\mathrm{mol} \%$; genome size, $870 \mathrm{kbp}$. Type strain is BARC $318^{\mathrm{T}}\left(=\right.$ ATCC $\left.51999^{\mathrm{T}}\right)$.

\section{REFERENCES}

1. Aluotto, B. B., Wittler, R. G., Williams, C. O. \& Faber, J. E. (1970). Standardized bacteriologic techniques for characterization of Mycoplasma species. Int J Syst Bacteriol 20 , $35-58$.

2. Artiushin, S., Duvall, M. \& Minion, F. C. (1995). Phylogenetic analysis of Mycoplasma strain ISM1499 and its assignment to the Acholeplasma oculi strain cluster. Int J Syst Bacteriol 45. 104 109.
3. Bentley, R. W., Leigh, J. A. \& Collins, M. D. (1991). Intrageneric structure of Streptococcus based on comparative analysis of small-subunit rRNA sequences. Int $J$ Syst Bacteriol 41, 487-494.

4. Brosius, J., Palmer, M. L., Kennedy, P. J. \& Noller, H. F. (1978). Complete nucleotide sequence of a $16 \mathrm{~S}$ rRNA gene from Escherichia coli. Proc Natl Acad Sci USA 75, 4801-4805.

5. Carle, P., Laigret, F., Bové, J. M. \& Tully, J. G. (1995). Heterogeneity of genome size measurements of the genus Spiroplasma. Int J Syst Bacteriol 45, 178-181.

6. Carle, P., Rose, D. L., Tully, J. G. \& Bové, J. M. (1992). The genome size of spiroplasmas and other mollicutes. IOM Lett 2, 263.

7. Carle, P., Saillard, C. \& Bové, J. M. (1983). DNA extraction and purification. Methods Mycoplasmol 1, 295-299.

8. Carle, P., Saillard, C. \& Bové, J. M. (1983). Determination of guanine plus cytosine content of DNA. Methods Mycoplasmol 1, 301-308.

9. Clyde, W. A., Jr (1983). Growth inhibition tests. Methods Mycoplasmol 1, 405-410.

10. Freundt, E. A. (1953). The occurrence of Micromyces (pleuropneumoniae-like organisms) in the female genito-urinary tract. Acta Pathol Microbiol Scand 32, 468-480.

11. Freundt, E. A. (1955). The classification of the pleuropneumonia group of organisms (Borrelomycetales). Int Bull Bacteriol Nomencl Taxon 5, 67-78.

12. Freundt, E. A. (1958). The Mycoplasmataceae. Copenhagen: E. Munksgaard.

13. Green, C. J., Stewart, G. C., Hollis, M. A., Vold, B. S. \& Bott, K. F. (1985). Nucleotide sequence of the Bacillus subtilis ribosomal RNA operon, $r m B$. Gene 37, 261-266.

14. International Committee on Systematic Bacteriology Subcommittee on the Taxonomy of Mollicutes (1995). Revised minimum standards for description of new species of the class Mollicutes (division Tenericutes). Int J Syst Bacteriol 45, 605-612.

15. Iwami, M., Muto, A., Yamao, F. \& Osawa, S. (1984). Nucleic acid sequence of the $r r n B$ 16S rRNA gene from Mycoplasma capricolum. Mol Gen Genet 196, 317-322.

16. Konai, M., Clark, E. A. \& Whitcomb, R. F. (1992). Temperature ranges, growth optima, and growth rates of Spiroplasma (Spiroplasmataceae class Mollicutes) species. Curr Microbiol 32, 1-7.

17. Maidak, B. L., Larsen, N., McCaughey, M. J., Overbeek, R., Olsen, G. J., Fogel, K., Blandy, J. \& Woese, C. R. (1994). The Ribosomal Database Project. Nucleic Acids Res 22, 34853487

18. McCoy, R. E., Basham, H. G., Tully, J. G., Rose, D. L., Carle, P. \& Bové, J. M. (1984). Acholeplasma florum, a new species isolated from plants. Int J Syst Bacteriol 34, 11-15.

19. Navas-Castillo, J., Laigret, F., Tully, J. G. \& Bové, J. M. (1992). Le mollicute Acholeplasma florum possède un gène du système phosphoénolpyruvate sucre- phosphotransferase et il utilize UGA comme codon tryptophane. $C R A c a d S c i$ (Paris) 315, 43-48.

20. Neimark, H. C. \& Carle, P. (1995). Mollicute chromosome size determination and characterization of chromosomes from uncultured mollicutes. In Molecular and Diagnostic Procedures in Mycoplasmology, vol. 1, pp. 119-131. Edited by S. Razin \& J. G. Tully. San Diego: Academic Press.

21. Olsen, G. J., Matsuda, H., Hagstrom, R. \& Overbeek, R. (1994). 
FastDNAml: a tool for construction of phylogenetic trees of DNA sequences using maximum likelihood. CABIOS 10, 41-48.

22. Page, R. D. M. (1996). TREeVIEw: an application to display phylogenetic trees on personal computers. Comput Appl Biosci 12, 357-358.

23. Rose, D. L., Tully, J. G., Bové, J. M. \& Whitcomb, R. F. (1993). A test for measuring growth responses of mollicutes to serum and polyoxyethylene sorbitan. Int $J$ Syst Bacteriol 43, 527-532.

24. Seemuller, E., Schneider, B., Maurer, R., Ahrens, U., Daire, X., Kison, H., Lorenz, K. H., Firrao, G., Avinent, L., Sears, B. B. \& Stackebrandt, E. (1994). Phylogenetic classification of phytopathogenic mollicutes by sequence analysis of $16 \mathrm{~S}$ rDNA. Int J Syst Bacteriol 44, 440-446.

25. Senterfit, L. B. (1983). Preparation of antigens and antisera. Methods Mycoplasmol 1, 401-404.

26. Taylor-Robinson, D. (1983). Metabolism inhibition tests. Methods Mycoplasmol 1, 411-417.

27. Tully, J. G. (1989). Class Mollicutes: new perspectives from plant and arthropod studies. In The Mycoplasmas, vol. 5, pp. 1-31. Edited by R. F. Whitcomb \& J. G. Tully. New York: Academic Press.

28. Tully, J. G. (1993). Cloning and filtration techniques for mycoplasmas. Methods Mycoplasmol 1, 173-177.

29. Tully, J. G. (1993). Serological identification of mollicutes. In Rapid Diagnosis of Mycoplasmas, pp. 121-130. Edited by I. Kahane \& A. Adoni. New York: Plenum.

30. Tully, J. G. (1995). Determination of cholesterol and polyoxyethylene sorbitan growth requirements of mollicutes. In Molecular and Diagnostic Procedures in Mycoplasmology, vol. 1, pp. 381-389. Edited by S. Razin \& J. G. Tully. San Diego: Academic Press.

31. Tully, J. G., Bové, J. M., Laigret, F. \& Whitcomb, R. F. (1993). Revised taxonomy of the class Mollicutes: proposed elevation of a monophyletic cluster of arthropod-associated mollicutes to ordinal rank (Entomoplasmatales ord. nov.), with provision for familial rank to separate species with nonhelical morphology (Entomoplasmataceae fam. nov.) from helical species (Spiroplasmataceae), and emended descriptions of the order Mycoplasmatales, family $M y<0-$ plasmataceae. Int $J$ Syst Bacteriol 43, 378-385.

32. Tully, J. G. \& Razin, S. (1996). Appendix. In Molecular and Diagnostic Procedures in Mycoplasmology, vol. 2, pp. 455-459. Edited by J. G. Tully \& S. Razin. San Diego: Academic Press.

33. Tully, J. G., Rose, D. L., Carle, P., Bové, J. M., Hackett, K. J. \& Whitcomb, R. F. (1988). Acholeplasma entomophilum sp. nov. from gut contents of a wide range of host insects. Int $J S_{y}$ st Bacteriol 38, 164-167.

34. Tully, J. G., Rose, D. L., Hackett, K. J., Whitcomb, R. F., Carle, P., Bové, J. M., Colflesh, D. E. \& Williamson, D. L. (1989).
Mycoplasma ellychniae sp. nov., a sterol-requiring mollicute from the firefly beetle Ellychnia corrusca. Int J Syst Bacteriol 39, $284-289$.

35. Tully, J. G., Rose, D. L., McCoy, R. E., Carle, P., Bové, J. M., Whitcomb, R. F. \& Weisburg, W. G. (1990). Mycoplasma melaleucae sp. nov., a sterol-requiring mollicute from flowers of several tropical plants. Int J Syst Bacteriol 40 , $143-147$.

36. Tully, J. G. \& Whitcomb, R. F. (1991). The genus Spiroplasma. In The Prokaryotes, vol. 2, 2nd edn, pp. 1960-1980. Edited by A. Balows, H. G. Trüper, M. Dworkin, W. Harder \& K.-H. Schleifer. New York: Springer-Verlag.

37. Tully, J. G., Whitcomb, R. F., Hackett, K. J., Rose, D. L., Henegar, R. B., Bové, J. M., Carle, P., Williamson, D. L. \& Clark, T. B. (1994). Taxonomic descriptions of eight new non-sterol-requiring mollicutes assigned to the genus Mesoplasma. Int J Syst Bacteriol 44, 685-693.

38. Tully, J. G., Whitcomb, R. F., Rose, D. L., Bové, J. M., Carle, P., Somerson, N. L., Williamson, D. L. \& Eden-Green, S. (1994). Acholeplasma brassicae sp. nov., and Acholeplasma palmae sp. nov., two non-sterol-requiring mollicutes from plant surfaces. Int $J$ Syst Bacteriol 44, 680-684.

39. Tully, J. G., Whitcomb, R. F., Rose, D. L., Hackett, K. J., Clark, E., Henegar, R. B., Carle, P. \& Bové, J. M. (1990). Current insight into the host diversity of acholeplasmas. Zentbl Bakteriol Mikrobiol Hyg Suppl 20, 461-467.

40. Walsh, P. S., Metzger, D. A. \& Higuchi, R. (1991). Chelex-100 as a medium for simple extraction of DNA for PCR-based typing from forensic material. Biotechniques 10, 506-513.

41. Weisburg, W. G., Tully, J. G., Rose, D. L., Petzel, J. P., Oyaizu, H., Yang, D., Mandelco, L., Sechrest, J., Lawrence, T. G., Van Etten, J., Maniloff, J. \& Woese, C. R. (1989). A phylogenetic analysis of the mycoplasmas: basis for their classification. $J$ Bacteriol 171, 6455-6467.

42. Whitcomb, R. F. (1983). Culture media for spiroplasmas. Methods Mycoplasmol 1, 147-158.

43. Whitcomb, R. F. \& Hackett, K. J. (1996). Identification of mollicutes from insects. In Molecular and Diagnostic Procedures in Mycoplasmology, vol. 2, pp. 313-322. Edited by J. G. Tully \& S. Razin. San Diego: Academic Press.

44. Williamson, D. L. (1983). Specialized electron microscopic techniques for spiroplasmas in plant and insect tissues. Methods Mycoplasmol 1, 71-76.

45. Williamson, D. L., Tully, J. G., Rose, D. L., Hackett, K. J., Henegar, R., Carle, P., Bové, J. M., Colflesh, D. E. \& Whitcomb, R. F. (1990). Mycoplasma somnilux sp. nov., Mycoplasma luminosum sp. nov., and Mycoplasma lucivorax sp. nov.. new sterol-requiring mollicutes from firefly beetles (Coleoptera: Lampyridae). Int J Syst Bacteriol 40, 160-164.

46. Williamson, D. L., Tully, J. G. \& Whitcomb, R. F. (1989). The genus Spiroplasma. In The Mycoplasmas, vol. 5, pp. 71-111. Edited by R. F. Whitcomb \& J. G. Tully. New York: Academic Press. 